\title{
Anoxic thermomineral cave waters and bacterial mats as habitat for freshwater nematodes
}

\author{
Wolfgang Riess ${ }^{1, *}$, Olav Giere ${ }^{2}$, Oliver Kohls ${ }^{1}$, Serban M. Sarbu ${ }^{3}$ \\ ${ }^{1}$ Max Planck Institute for Marine Microbiology, Celsiusstr. 1, D-28359 Bremen, Germany \\ ${ }^{2}$ Zoological Institute and Zoological Museum, University of Hamburg, Martin-Luther-King-Platz 3, D-20146 Hamburg, \\ Germany \\ ${ }^{3}$ Department of Biological Sciences, University of Cincinnati, 821-A Rieveschl Hall, Cincinnati, Ohio 45221-0006, USA
}

\begin{abstract}
A unique chemoautotrophic system of floating microbial mats was examined in a subterranean cave in southern Romania. Oxygen measurements were made with a recently developed technique applying micro-optodes. The oxygen uptake rate of the anoxic and sulfidic cave waters over the atmosphere/water interface was as high as $103.3 \pm 9.1 \mathrm{mmol} \mathrm{O}_{2} \mathrm{~m}^{-2} \mathrm{~d}^{-1}$. Floating microbial mats consisting primarily of sulfide oxidizers and fungal mycelia were found to be adapted to reduced oxygen supply and thrived even under strict anoxia. These $2 \mathrm{~mm}$ thick mats were inhabited by 5 different species of nematodes, reaching densities of $9.8 \times 10^{6}$ ind. $\mathrm{m}^{-2}$ Possible alternative pathways for growth of the mats and also for the persistence and reproduction of nematodes under strict anoxic conditions are discussed.
\end{abstract}

KEY WORDS: Microbial mat C Chemoautotrophic C Cave $\cdot$ Nematodes A Anoxia $\cdot$ Optode

\section{INTRODUCTION}

The ability to survive in anoxic (and sulfidic) environments has been reported for many Protozoa and Metazoa (Bryant 1991, Giere 1992, Grieshaber et al. 1994, Fenchel \& Finlay 1995, Hochachka 1997, Grieshaber \& Völkel 1998). In sediments, the question whether a 'thiobios' exists and how it is to be defined has been long debated after the first description of the sulfide system by Fenchel \& Riedl (1970). There is a consensus that many taxa can live for extended periods of time without oxygen and, thus, are well adapted to hypoxia (i.e. exhibit physiological or behavioural adaptations). But reports regarding Metazoa that live permanently under anoxic conditions remain circumstantial without detailed experimental proof whether the populations examined were able to temporarily take up traces of oxygen by moving within the vertical gradients or by extending at least a part of their body into oxic layers or microniches. Thus, the supply of some oxygen cannot be excluded (Fenchel \& Finlay 1991, 1995). In contrast to specialized Protozoa

•E-mail: biblio@mpi-bremen.de
(Fenchel \& Finlay 1995), all free-living and parasitic Metazoa seem to need oxygen at least for their reproductive stages (i.e. eggs, larvae) (Barrett 1991).

A community of 5 nematode species was discovered thriving within floating microbial mats under completely anoxic, experimental conditions for several months in a thermomineral sulfide-rich groundwater system in Movile Cave, Romania.

A recently developed, extremely sensitive oxygen detector with very high spatial resolution and capable of detecting even traces of oxygen (detection limit 10 ppb, Klimant et al. 1997) was used to confirm complete anoxia.

The Movile Cave groundwater system was discovered in 1986 (Lascu 1989). It contains a rich and abundant community of aquatic and terrestrial invertebrates isolated from the surface for a considerable amount of time (Sarbu \& Kane 1995). The subterranean ecosystem is based entirely on food produced in situ by chemoautotrophic microorganisms (Sarbu et al. 1996). Sulfur-oxidizing and methane-oxidizing bacteria were identified in samples of water and microbial mats from Movile Cave (Sarbu et al. 1994, 1996, Vlasceanu et al. 1997). 


\section{MATERIAL AND METHODS}

Site. Movile Cave is located in Southern Dobrogea, Romania, close to the coastline of the Black Sea and to the town of Mangalia (Fig. 1). Large subterranean voids of karst origin host a captive thermomineral sulfidic aquifer at depths of $200 \mathrm{~m}$ below the surface. In the Mangalia region these waters ascend to the surface along natural faults. They form natural springs and are found as sulfidic groundwaters in the superficial Sarmatian limestones (Lascu 1989).

Movile Cave, a $240 \mathrm{~m}$ long system of natural cave passages located $20 \mathrm{~m}$ under the surface, was discovered in 1986 when an artificial shaft intercepted a section of the cave. A small lake in the deep section of Movile Cave (Fig. 2) permits access to the lower level of the cave, which is partially flooded by thermomineral water and contains several air bells (Sarbu \& Kane 1995).

The air in the lake room has an oxygen content close to normal epigean air conditions $\left(\mathrm{O}_{2}: 20 \%, \mathrm{CO}_{2}: 1.5 \%\right)$ whereas in the small adjacent air bells, which can be reached by divers only, the oxygen content is lower and $\mathrm{CO}_{2}$ and methane concentrations are higher $\left(\mathrm{O}_{2}: 7\right.$ to $10 \%, \mathrm{CO}_{2}: 2$ to $3.5 \%, \mathrm{CH}_{4}: 1 \%$ ) (Sarbu \& Popa 1992 , this study, Fig. 2).

The specific physico-chemical conditions at the interface between the thermomineral sulfidic water and the significantly modified atmospheric conditions in the cave's air bells allow the development of floating microbial mats which can attain a thickness of 2 to $3 \mathrm{~mm}$ (Fig. 2). The oxygen-rich atmosphere in the lake room prevents the development of floating microbial

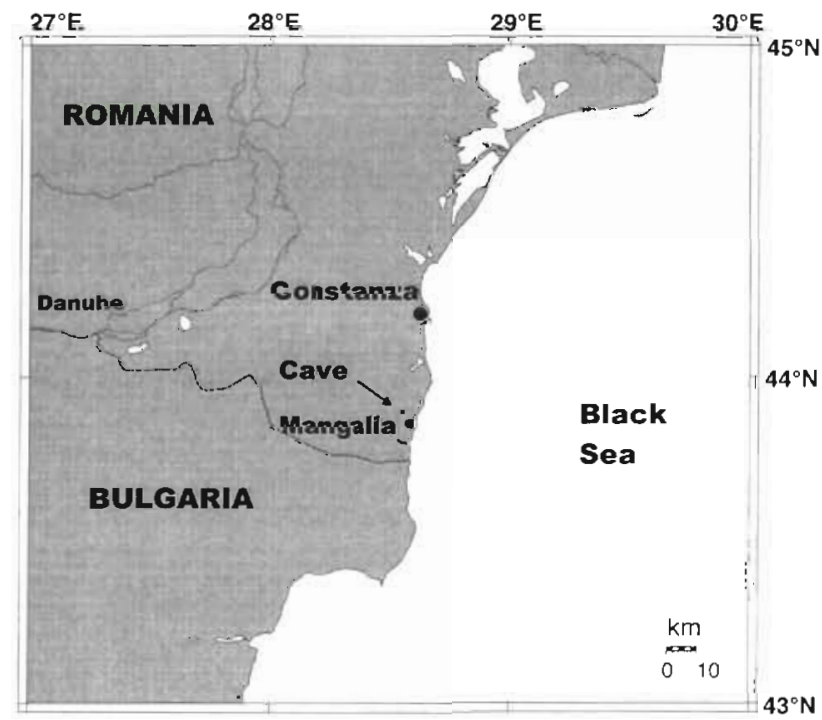

Fig. 1. Location of the cave in Southern Dobrogea in the southeast of Romania mats on the surface of the lake. In 1992, plexiglass enclosures were set afloat on the surface of the lake to create artificial air bells (Fig. 2). Openings in their walls allowed a controlled access of oxygen. Floating microbial mats developed in those artificial air bells, whose atmosphere resembled that within the cave's natural air bells.

Sampling. Biological samples were collected and in situ measurements of the physico-chemical parameters of the subterranean environment were performed in Movile Cave and in other sulfide-rich epigean habitats in April 1994, April 1996, November 1996 and July 1998. Several different habitats were screened for the presence of meiofauna. Samples of microbial mats with their inhabitant fauna and some original water were collected in Movile Cave in April 1994 and were cultured in $50 \mathrm{ml}$ centrifuge tubes (Sarstedt). The tubes, which were sealed and stored in an air-tight container in the dark at room temperature, were opened 11 mo later and inspected for living animals. Additional vials containing mat material were fixed with buffered formaldehyde solution (final concentration approx. $5 \%$ ) immediately after sampling. Nematodes living in the dense microbial mat substrate were sorted out and counted under a dissecting microscope immediately after return to the Center for Ecological Research, in Mangalia. Some specimens were mounted on permanent slides (Riemann 1988) and stored for later identification.

Mat material from the anoxic artificial air bells was frozen and later processed with the French press technique (American Instruments Co. Inc., Silver Spring, USA) to measure nitrate accumulation within the cells and/or mat. The nitrate measurements were done using a $42 \mathrm{C} \mathrm{NO}-\mathrm{NO}_{2}-\mathrm{NO}_{x}$ Analyzer (Thermo Environmental Instruments, Reference Method RFNA-1289074) (see Braman \& Hendrix 1989).

Water samples were collected in $5 \mathrm{~cm}$ intervals between 5 and $90 \mathrm{~cm}$ using $1 \mathrm{ml}$ syringes to determine the concentration of hydrogen sulfide (total soluble sulfide: $\mathrm{H}_{2} \mathrm{~S}, \mathrm{HS}^{-}, \mathrm{S}^{2-}$ ) in the cave water. The samples were fixed with alkaline zinc-acetate solution and were measured photometrically (Gilboa-Garber 1971 , modified). The chemical composition of the atmosphere in the lake room and in the artificial air bells was determined using a Dräger hand pump (accuro) and Dräger test tubes for oxygen (no. 6728081), carbon dioxide (no, 8101931) and hydrogen sulfide (no. $6728041)$.

High resolution measurements of oxygen concentrations in the water column were performed in November 1996 in the cave lake and in the artificial air bells. A fiber optical microsensor (optode) (Klimant et al. 1995) was connected to an autonomous electronic system (Glud et al. 1999) suitable for the specific demands 


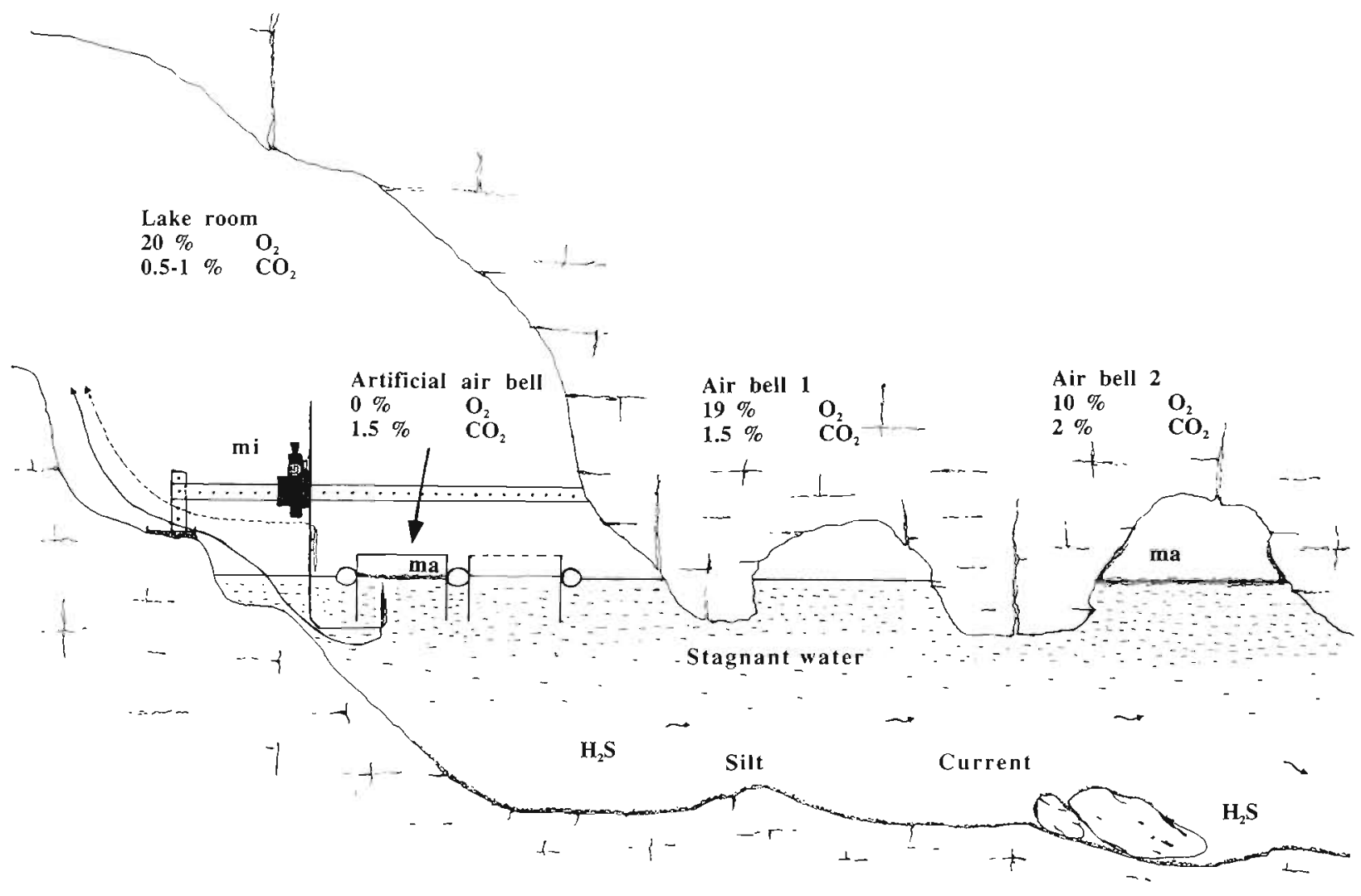

Fig. 2. Transect through the cave. Oxygen and $\mathrm{CO}_{2}$ contents of the different compartments are given in vol. \%. The oxygen measuring setup includes a micromanipulator (mi) for accurate positioning of the optodes mounted in different ways. ivicrobial mats (ma) only form where oxygen is significantly reduced

of the cave environment. This battery powered system was used for one of the first in situ measurements within the frame of an ecological study.

Optode measurements. The principle of fiber optic oxygen measurements is luminescence quenching of a dye which is sensitive to oxygen. This type of sensor was chosen over the traditional Clark-type electrode since it does not consume oxygen and thus lacks a stirring effect. Additionally optodes have their highest sensitivity at low oxygen concentrations (because of a non-linear relation between oxygen concentration and optical signal). A 100/140 micrometer silica/silica graded index fiber material (Radiall, Germany) was used for the preparation of fiber optical microsensors (optodes). Previous experiments have shown that it is important to create a rather short taper at the tip and to cover only the very tip of the fiber with the sensor chemistry and the insulation. Taking these measures, a good signal to noise ratio can be achieved. Matrix material and dye solution were dissolved in chloroform with a dye concentration in the polystyrene of $5 \mathrm{mM}$.

A description of the optical measuring system is given by Klimant et al. (1995) and more recently by Glud et al. (1999). A fitted function was used for the calibration of the optode. This function was determined by adjusting the sensor signal to 9 different oxygen concentrations $(0,5,10,25,40,55,70,85,100 \%$ air saturation). Based on this function, the optode was calibrated before the measurement at 0 and $100 \%$ air saturation. The detection limit for oxygen of $10 \mathrm{ppb}\left(\mathrm{O}_{2}\right.$ dissolved in water) can be reduced to $0.5 \mathrm{ppb}$ (or $0.1 \mu \mathrm{M}$ ) by using a newly developed dye/matrix system (Klimant pers. comm., Kühl \& Revsbech in press).

Oxygen profiles in the cave water were measured in the uppermost layers of the lake's open water to determine the depth of oxygen penetration into the water column and to calculate oxygen fluxes under normoxic conditions. In the open water of the cave lake, oxygen profiles were taken at $100 \mu \mathrm{m}$ intervals. Corresponding profiles were measured in the artificial anoxic air bell to prove that oxygen was absent in the enclosed floating mats and in the underlying water. Oxygen concentrations in the water column and in the floating microbial mats under the artificial air bells were first measured from under the water surface, and the optode was then lifted toward the surface in $1 \mathrm{~mm}$ increments. Within the floating microbial mats measurements were done at $100 \mu \mathrm{m}$ intervals. 
Fick's first law of diffusion was used for the calculation of oxygen fluxes:

$$
\mathrm{J}=-D_{0} \times \mathrm{d} C / \mathrm{d} z
$$

where $D_{0}$ is the diffusion coefficient in the water at the ambient temperature and salinity and $\mathrm{d} C / \mathrm{d} z$ is the change in oxygen concentration over a discrete depth interval. We assumed molecular diffusion as the mode of transport, mass conservation of oxygen and a 1 dimensional flux of oxygen into the water.

\section{RESULTS}

The atmosphere in the cave appeared to be free of $\mathrm{H}_{2} \mathrm{~S}$ since it was not detected by its characteristic smell (detection limit at concentrations of 0.03 to $1 \mathrm{ppm}$; see Marquardt \& Schäfer 1994). A slight stirring of the water surface of the lake caused a very strong smell of hydrogen sulfide, which indicated that only a very thin superficial layer of the water was devoid of free sulfide. The water temperature was stable at 20.5 $\pm 0.1^{\circ} \mathrm{C}$, as was the $\mathrm{pH}$ at 7.4 . The total mineral content was $1 \mathrm{~g} \mathrm{l}^{-1}$, of which $0.5 \mathrm{~g}$ represented bicarbonates and $0.4 \mathrm{~g} \mathrm{NaCl}$. Sulfate reached values of up to $64 \mu \mathrm{mol} \mathrm{l}^{-1}$, and nitrate was as low as $8 \mu \mathrm{mol} \mathrm{l}^{-1}$.

\section{Oxygen/sulfide conditions and fluxes at the water surface}

Lake water

A steep oxygen gradient was measured in the lake water with an oxygen penetration depth of $0.8 \mathrm{~mm}$ (Fig. 3). This gradient served as a basis for calculating the fluxes of oxygen from the atmosphere into the water and yielded oxygen uptake rates of $103.3 \pm 9.1$ mmol $\mathrm{O}_{2} \mathrm{~m}^{-2} \mathrm{~d}^{-1}$. The sulfide content in the water column was $300 \pm 34 \mu \mathrm{mol} \mathrm{I^{-1 }}$ This value remained fairly constant throughout the water column from 5 to $90 \mathrm{~cm}$ depth. A steep gradient in sulfide concentrations appeared to exist between the water surface and a depth of $5 \mathrm{~cm}$, but no measurements were performed above $5 \mathrm{~cm}$. Assuming a sulfide gradient ranging from $0 \mu \mathrm{mol} \mathrm{l}^{-1}$ at the water surface to $325 \mu \mathrm{mol} \mathrm{l}^{-1}$ at a depth of about 0.8 to $0.9 \mathrm{~mm}$, where no traces of oxygen could be detected, the upward flux of sulfide was calculated to be $64.2 \mathrm{mmol} \mathrm{m} \mathrm{m}^{-2} \mathrm{~d}^{-1}$.

\section{Artificial air bell}

Within the artificial air bell, there was complete anoxia both in the water column and in the microbial

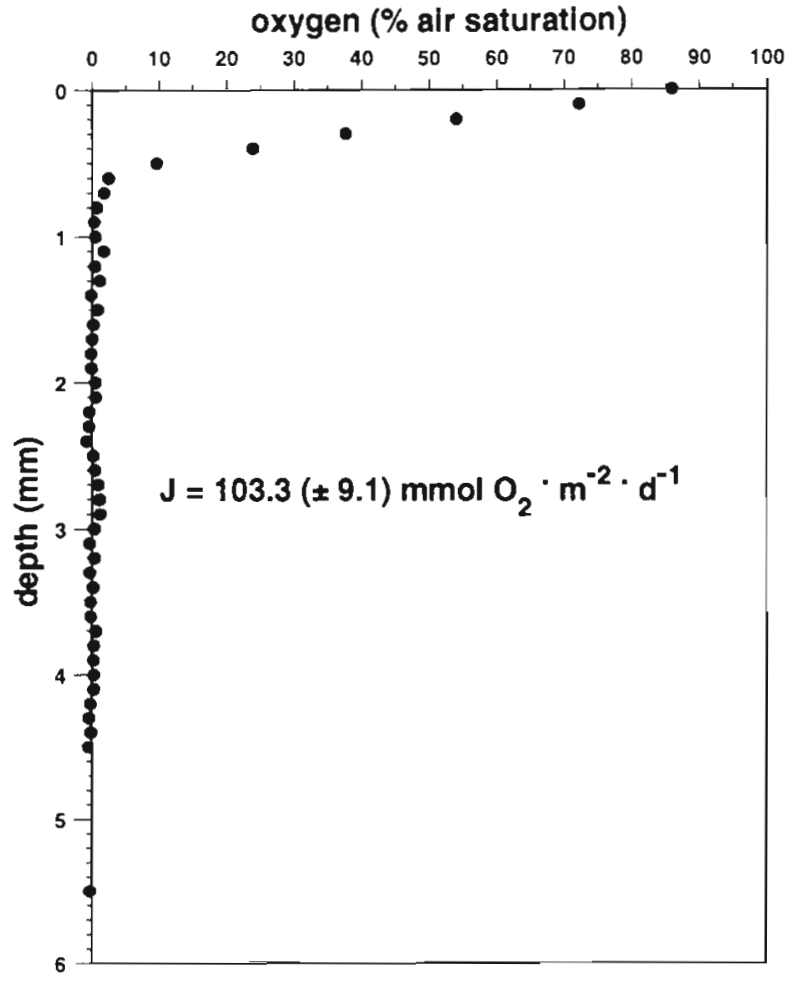

Fig. 3. Oxygen profile at the lake's water surface without a floating mat. Depth resolution of $100 \mu \mathrm{m}$. Oxygen penetration depth $0.8 \mathrm{~mm}$

mat (Fig. 4). As soon as the optode's sensor tip was out of the mat and into the air, a significant leap of the measured signal was seen due to different refractory indices of the aqueous and gas phase (data not shown), indicating the position of the mat/atmosphere interface. In addition, no oxygen was found in the atmosphere entrapped in the experimental air bell that was isolated from the cave's atmosphere. Free hydrogen sulfide was measured in the atmosphere under the anoxic tank but the values exceeded $15 \mathrm{ppm}$, which was the upper limit of the Dräger test tubes used.

\section{Microbial mats}

As predicted from the observations in the natural air bells, where mats occurred naturally, microbial mats developed only under those experimental tanks with hypoxic conditions above the water surface. However, a thick microbial mat also developed in the anoxic tank completely isolated from the cave air. Mats consisted of a variety of sulfide oxidizing bacteria such as Thiotrix spp., large gliding Beggiatoa spp., Beggiatoa-like immobile bacteria and Thiospira spp. (Küver pers. comm.). Thiobacillus thioparus was identified with molecular techniques by Vlasceanu et al. (1997). $\mathrm{S}_{0}$ aggregates within the mats indicated sulfide oxidizing 
activity by bacteria. In addition to sulfur bacteria spirochaetes were also found in the mats (Küver pers. comm.). The texture of the mats is stabilized by a significant component of fungal mycelia. Within the processed samples of the anoxic mat material we measured nitrate values (serving as a potential electron acceptor for the sulfide oxidizing bacteria) of $156 \mu \mathrm{mol} \mathrm{l}^{-1}$.

\section{Fauna inhabiting the mats}

The fauna of the mats is dominated by nematodes and flagellates. The highest populations of nematodes were found in the mats under the experimental tank experiencing complete anoxia for at least several months. The density of the animals within the $2 \mathrm{~mm}$ thick mat was calculated to be $9.8 \times 10^{6}$ ind. $\mathrm{m}^{-2}$, which is in the order of magnitude of the highest reported densities in organic-rich Wadden Sea areas (Giere 1993). Cultivation experiments with some mat material and original water showed that the nematodes could be kept alive and active for more than 1 yr without any supply of oxygen in a clearly sulfidic environment (smell!)

To date, 5 nematode species have been found in the mats. These include Chronogaster troglodytes sp. n., an endemic species described from Movile Cave (Poinar \& Sarbu 1994), Panagrolaimus sp., Protorhabditis sp., Udonchus tenuicaudatus and 1 species probably belonging to the genus Monhystrella. Ultrastructural studies on the nematode species are currently being performed.

\section{DISCUSSION}

\section{Growth of microbial mats and presence of nematodes}

\section{Normoxic conditions}

Floating microbial mats do not occur under the normoxic surface conditions in the open lake. Only a very thin film is clearly detectable on the water surface. According to the stoichiometry of the oxidation of reduced sulfur, the gradients we found $-\mathrm{J}\left(\mathrm{O}_{2}\right): \mathrm{J}\left(\mathrm{S}^{2-}\right)$ ratio of 1.6 - suggest an oxidation of $\mathrm{H}_{2} \mathrm{~S}$ to thiosulfate oxygen (\% air saturation)

0

25

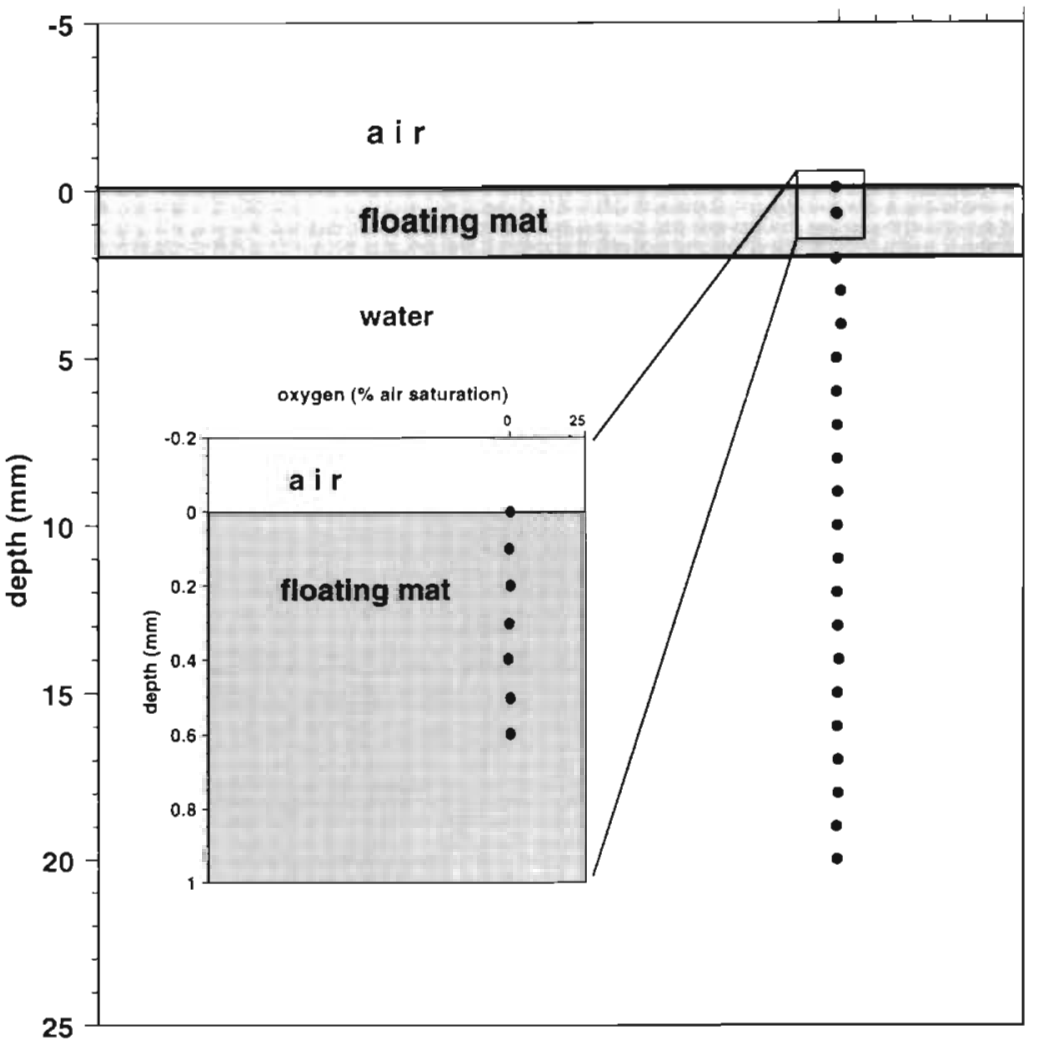

Oxygen measurement in the artificial air bell. Depth resolution
Inset: uppermost millimeter of the mat, depth resolution $100 \mu \mathrm{m}$

or even to sulfate with a $\mathrm{J}\left(\mathrm{O}_{2}\right): \mathrm{J}\left(\mathrm{S}^{2-}\right)$ ratio of 1 or 2 respectively. Therefore, growth of sulfide oxidizers is not limited since there are also substantial amounts of dissolved inorganic carbon as a potential carbon source. On the other hand, we found a high number of heterotrophs mainly in the upper thin water layer $(0.8 \mathrm{~mm})$ that contains oxygen; especially flagellates and crustaceans reach high numbers. It seems very likely that these heterotrophs cause a significant grazing effect on the microorganisms as long as they have enough oxygen.

Since the habitat for substrate-depending forms like nematodes is limited, nematodes occur in small numbers only. Nematodes tend to stay in contact with a certain substrate, but they are able to swim and were present in small numbers in the uppermost layer of the water column.

\section{Hypoxic conditions}

The situation changes when conditions become hypoxic in the air bells. Reduced grazing permits the 
development of thick floating microbial mats consisting not only of sulfide oxidizers but also of significant amounts of fungal mycelia. Large numbers of nematodes live within these mats. Despite the hypoxic conditions there is enough oxygen in the water and in the mats for the sulfide oxidizers and for the nematodes to perform aerobic respiration. Gnaiger (1991) found that even under $0.5 \%$ air saturation animals were able to fulfill one-third of their metabolism aerobically. An oxygen content of $10 \%$ in the air bell's atmosphere is thus not a major problem for the nematodes' metabolism and obviously also not for reproduction.

\section{Anoxic conditions}

Under the artificial enclosures floating on the water surface in the lake room, conditions are completely anoxic (Fig. 4). Nevertheless floating mats started to form only $15 \mathrm{~d}$ after the enclosures were installed and the mats reached the final $2 \mathrm{~mm}$ thickness about 5 mo later. Diffusion of oxygen through plexiglass was calculated to account for a daily oxygen flux that corresponds to only $0.23 \%$ of the total volume of air under the experimental tank (for calculation see Smith et al. 1997). Free hydrogen sulfide was measured in the entrapped atmosphere, also indicating the absence of oxygen and reducing conditions. Since the oxygen that existed at the start of the experiment is depleted within approximately $9 \mathrm{~d}$, the sulfide oxidizers have to switch to a different electron acceptor. Nitrate is sparse in the water column, but Fossing et al. (1995) and McHatton et al. (1996) showed that Thioploca spp. and Beggiatoa spp. are able to accumulate nitrate in their vacuoles up to 4000 -fold compared to the ambient water. The nitrate measurements of the anoxic mat material showed the increase of nitrate to be approximately 20 fold compared to the ambient water (156 and $8 \mu \mathrm{M}$ respectively). The low nitrate content in the water and the possible need to accumulate an electron acceptor could be an explanation for the relatively slow growth of the microbial mats under anoxic conditions.

Surprisingly, the highest numbers of nematodes were found in these anoxic mats. As noted above, only a very small number of nematodes was present in the enclosures at the start of the experiment. As conditions became anoxic very soon after the installation of the enclosures, it is hard to assume that nematodes would be attracted from the surrounding body of water. In addition, millions of animals would have to swim distances of several meters out of their original habitat, the floating mats in the cave's natural air bells. The chamber walls descended $15 \mathrm{~cm}$ into the cave water, representing a barrier to nematode migration into the chamber. Thus, the high population density in these mats is assumed to result from in situ reproduction.

\section{Growth and reproduction under anoxic conditions}

The term anoxia, its definition, and the ability of guaranteeing anoxia under experimental conditions have been widely discussed in the literature (overview see Gnaiger 1991). It is significant whether animals have to face anoxia or just hypoxla. Measuring very low levels of oxygen is difficult and highly dependent on the method used. So far this has limited the interpretation of true anoxic conditions. The oxygen optode is very sensitive to small quantities of $\mathrm{O}_{2}$. In addition we found a habitat with extraordinarily high chemical and biological oxygen uptake rates, thus limiting the access of $\mathrm{O}_{2}$ to the nematodes even if a few molecules of oxygen might still get into the system.

Nitrate respiration has never been reported from nematodes although experiments have been performed to determine its existence (Riemann pers. comm.). Previous reports of metazoans living and reproducing under anoxia (Famme \& Knudsen 1984, 1985) have been disputed in the literature (Gnaiger \& Staudigl 1987, Schöttler \& Bennet 1991).

Adult animals in the floating mats are not food limited. Thus, survival under anoxia would be possible even taking into account the low efficiency of anaerobic pathways. Energy production would therefore not be critical. For reproduction on the other hand, especially for the development of eggs, there must be another more efficient pathway of energy production with an inorganic electron acceptor, since the energy demand for the early reproductive stages is very high (especially for cell divisions). Jensen (1995) found only reproductive adults of the nematode Theristus anoxybioticus at the oxygenated sediment surface of muddy sediments (at methane seepages, northern Kattegat, Denmark) for a short period of time whereas juveniles were typically restricted to the deeper anoxic layers, suggesting that even this facultative anaerobe nematode needed to reach oxygen for its reproduction. Other oxygen sensitive processes, for example the collagen synthese (Barrett 1991), have also to be taken into account

If we assume the nitrate accumulation in the microbial mat to be significant and look for a way for the nematodes to benefit from this source of electron acceptor, the next step would be to search for (1) modifications in mitochondria; several authors found that the ultrastructure of mitochondria/hydrogenosomes changed with the occurrence of nitrate reduction in organisms like the ciliate Loxodes (Finlay et al. 1983, Finlay 1985) or in other animals from anoxic or sulfidic 
environments (overview see Dubilier 1992); (2) the presence of symbiotic bacteria; and (3) the presence of nitrate reductase in the animals or in symbionts.

Other questions arise regarding the detoxification of sulfide in the absence of oxygen. In the presence of oxygen, detoxification could take place to a certain level (Dubilier 1992, Völkel \& Grieshaber 1991). Vismann (1991) grouped the physiological mechanisms of sulfide defenses into a hierarchy and suggested a distinction between sulfide-tolerant and non-tolerant species. Somero et al. (1989) described that in most cases the resistance of animals against the poisoning effects of sulfide is achieved by preventing sulfide from reaching sensitive areas in the body. Powell (1989) stated that thiobiotic meiofauna must be sulfide insensitive, which is relevant especially under anoxic conditions when animals switch to an anaerobic metabolism. Detoxification of sulfide might therefore not be critical. However other possible metabolic consequences such as disruptive effects on proteins caused by $\mathrm{H}_{2} \mathrm{~S}$ (Vetter et al. 1991) have to be taken into account.

Acknowledgements. This project was supported by the Volkswagen Foundation, Germany (No. I/71 041). V. Meyer (MPI) built much of the electronics and adapted it for use in the cave, for which we are very grateful. We thank F. Riemann for his advice in identifying the nematodes and for helpful suggestions. We also thank the members of the GESS team for support during field work. The manuscript benefited from the comments of 3 reviewers for which we are also very grateful.

\section{LITERATURE CITED}

Barrett J (1991) Parasitic helminths. In: Bryant C (ed) Metazoan life without oxygen. Chapman and Hall, London, p 146-164

Braman RS, Hendrix SA (1989) Nanogram nitrite and nitrate determination in environmental and biological materials by vanadium (III) reduction with chemoluminescence detection. Anal Chem 61:2715-2718

Bryant C (1991) Metazoan life without oxygen. Chapman and Hall, London

Dubilier N (1992) Ökophysiologische und morphologische Anpassungen des marinen Oligochaeten Tubificoides benedii (d'Udekem) an Sauerstoffmangel und Sulfid. Dissertation, University of Hamburg

Famme P, Knudsen $J$ (1984) Total heat balance study of anaerobiosis in Tubifex tubifex (Müller). J Comp Physiol 154:587-591

Famme P, Knudsen J (1985) Anoxic survival growth and reproduction by the freshwater annelid Tubifex sp. demonstrated using a new simple anoxic chemostat. Comp Biochem Physiol 81A:251-253

Fenchel T, Finlay BJ (1991) The biology of free-living anaerobic ciliates. Eur J Protistol 26:201-215

Fenchel T, Finlay BJ (1995) The evolution of life without oxygen. In: Slatkin M (ed) Exploring evolutionary biology. Sinauer Associates Inc, Sunderland, p 123-130

Fenchel TM, Riedl RJ (1970) The sulfide system: a new biotic community underneath the oxidized layer of marine sand bottoms. Mar Biol 7:255-268
Finlay BJ (1985) Nitrate respiration by Protozoa (Loxodes spp.) in the hypolimnetic nitrite maximum of a productive freshwater pond. Freshw Biol 15:333-346

Finlay BJ, Span ASW, Harman JMP (1983) Nitrate respiration in primitive eukaryotes. Nature 303:333-336

Fossing $H$, Gallardo VA, Jörgensen BB, Huttel M, Nielsen LP, Schulz H, Canfield DE, Forster S, Glud RN, Gundersen JK, Küver J, Ramsing NB, Teske $A$, Thamdrup $B$, Ulloa $O$ (1995) Concentration and transport of nitrate by the matforming sulphur bacterium Thioploca. Nature 374: $713-715$

Giere O (1992) Benthic life in sulfidic zones of the sea - ecological and structural adaptations to a toxic environment. Verh Dtsch Zool Ges 85:77-93

Giere O (1993) Meiobenthology. Springer-Verlag, Berlin

Gilboa-Garber N (1971) Direct spectrophotometric determination of inorganic sulfide in biological materials and in other complex mixtures. Anal Biochem 43:129-133

Glud RN, Klimant I, Holst G, Kohls O, Meyer V, Kühl M, Gundersen JK (1999) Adaptation, test and in situ measurements with $\mathrm{O}_{2}$ microoptodes on benthic landers. Deep-Sea Res (Instruments and Methods) 46:171-183

Gnaiger E (1991) Animal energetics at very low oxygen: information from calorimetry and respirometry. In: Woakes AJ, Grieshaber MK. Bridges CR (eds) Physiological strategies for gas exchange and metabolism. Cambridge University Press, Cambridge, p 149-171

Gnaiger E, Staudigl I (1987) Aerobic metabolism and physiological responses of aquatic oligochaetes to environmental anoxia: heat dissipation, oxygen consumption, feeding and defecation. Physiol Zool 60(6):659-677

Grieshaber M, Völkel S (1998) Animal adaptations for tolerance and exploitation of poisonous sulfide. Annu Rev Physiol 60:33-53

Grieshaber MK, Hardewig I, Kreutzer U, Poertner HO (1994) Physiological and metabolic responses to hypoxia in invertebrates. Rev Physiol Biochem Pharmacol 125:43-147

Hochachka PW (1997) Oxygen--a key regulatory metabolite in metabolic defense against hypoxia. Am Zool 37:595-603

Jensen P (1995) Theristus (Penzancia) anoxybioticus n. sp. (Nematoda: Xyalidae) from sublittoral methane seepages in the northern Kattegat, Denmark. J Nematol 27(2): $231-236$

Klimant I, Meyer V, Kühl M (1995) Fiber optic oxygen microsensor, a new tool in aquatic biology. Limnol Oceanogr 40(6): 1159-1165

Klimant I, Kühl M, Glud RN, Holst G (1997) Optical measurement of oxygen and temperature in microscale: strategies and biological applications. Sens Actuators B 38-39:29-37

Kühl M, Revsbech NP (in press) Microsensors for the study of interfacial biochemical processes. In: Boudreau BP, Jørgensen BB (eds) The benthic boundary layer. Oxford University Press, Oxford

Lascu C (1989) Paleogeographical and hydrogeological hypothesis regarding the origin of a peculiar cave fauna. Misc Speol Romanica, Bucaresti 1:13-18

Marquardt H, Schäfer SG (1994) Lehrbuch der Toxikologie. Bibliographisches Institut \& F.A. Brockhaus AG, Mannheim

McHatton SC, Barry JP, Jannasch HW, Nelson DC (1996) High nitrate concentrations in vacuolate, autotrophic marine Beggiatoa spp. Appl Environ Microbiol 62(3): $954-958$

Poinar GO Jr, Sarbu SM (1994) Chronogaster troglodytes sp. n. (Nematoda: Chronogasteridae) from Movile Cave, with a rewiev of cavernicolous nematodes. Fundam Appl Nematol 17:231-237 
Powell E (1989) Oxygen, sulfide and diffusion: why thiobiotic meiofauna must be sulfide-insensitive first-order respirers. J Mar Res 47:887-932

Riemann F (1988) Nematoda. In: Higgins RP, Thiel H (eds) Introduction to the study of meiofauna. Smithsonian Institution Press, Washington, p 293-301

Sarbu SM, Kane TC (1995) A subterranean chemoautotrophically based ecosystem. NSS Bull 57:91-98

Sarbu SM, Popa R (1992) A unique chemoautotrophically based cave ecosystem. In: Camacho Al (ed) The natural history of biospeleology. Monografias Museo Nacional de Ciencias Naturales, Madrid, p 638-666

Sarbu SM, Kinkle BK, Vlasceanu L, Kane TC, Popa R (1994) Microbiological characterisation of a sulfurous thermal groundwater ecosystem. Geomicrobiol J 12:175-182

Sarbu SM, Kane TC, Kinkle BK (1996) A chemoautotrophically based cave ecosystem. Science 272: 1953-1955

Schöttler U, Bennet EM (1991) Annelids. In: Bryant C (ed) Metazoan life without oxygen. Chapman and Hall, London, p 165-185

Editorial responsibility: Tom Fenchel,

Helsingør, Denmark
Smith KL JR, Glatts RC, Baldwin RJ, Beaulieu SE, Uhlman $\mathrm{AH}_{1}$ Horn RC, Reimers CE (1997) An autonomous, bottomtransecting vehicle for making long time-series measurements of sediment community oxygen consumption to abyssal depths. Limnol Oceanogr 42(7):1601-1612

Somero GN, Childress JJ, Anderson AE (1989) Transport, metabolism and detoxification of hydrogen sulfide in ani. mals from sulfide-rich marine environments. Rev Aquat Sci 1:591-614

Vetter RD, Powell MA, Somero GN (1991) Metazoan adaptations to hydrogen sulphide. In: Bryant $C$ (ed) Metazoan life without oxygen. Chapman and Hall, London, p 109-128

Vismann B (1991) Sulfide tolerance: physiological mechanisms and ecological implications. Ophelia 34(1):1-27

Vlasceanu L, Popa R, Kinkle BK (1997) Characterization of Thiobacillus thioparus LV43 and its distribution in a chemoautotrophically based groundwater ecosystem. Appl Environ Microbiol 63:3123-3127

Völkel S, Grieshaber MK (1991) Schwefelwasserstofftoleranz und -entgiftung beim Wattwurm Arenicola marina. Verh Dtsch Zool Ges 84:433

Submitted: August 17, 1998; Accepted: January 8, 1999

Proofs received from author(s): July 20, 1999 